HANDEL AS ORPHEUS 



\title{
Handel as Orpheus
}

\author{
VOICE AND DESIRE IN THE
}

CHAMBER CANTATAS

\section{Ellen T. Harris}

HARVARD UNIVERSITY PRESS

Cambridge, Massachusetts, and London, England • $200 \mathrm{I}$ 
Copyright $\left({ }_{0}\right.$ 200I by the President and Fellows of Harvard College All rights reserved

Printed in the United States of America

Publication of this book has been supported through the generous provisions of the Maurice and Lula Bradley Smith Memorial Fund and by a grant from the Massachusetts Institute of Technology.

\section{Library of Congress Cataloging-in-Publication Data}

Harris, Ellen T.

Handel as Orpheus : voice and desire in the chamber cantatas / Ellen T. Harris.

p. $\mathrm{cm}$.

Includes bibliographical references and index.

ISBN 0-674-00617-8 (alk. paper)

I. Handel, George Frideric, 1685-1759. Cantatas. 2. Cantata. 3. Homosexuality and music. I. Title.

$$
\begin{aligned}
& \text { ML4Io.Hi3 } \mathrm{H}_{283} \text { 2OOI } \\
& 782.4^{\prime} 8^{\prime} \text { 092—dc2I } \\
& 2001039075
\end{aligned}
$$


For my husband, John 
